] O U R A L O F

French and Francophone Philosophy
REVUE DE LA

philosophie française et de langue française

\title{
Statues Also Die
}

\section{Pierre-Philippe Fraiture}

Journal of French and Francophone Philosophy - Revue de la philosophie française et de langue française, Vol XXIV, No 1 (2016) 45-67.

\author{
Vol XXIV, No 1 (2016) \\ ISSN 1936-6280 (print) \\ ISSN 2155-1162 (online) \\ DOI $10.5195 /$ jffp. 2016.757 \\ www.jffp.org
}

\section{(c) BY-NC-ND}

This work is licensed under a Creative Commons Attribution-Noncommercial-No Derivative Works 3.0 United States License.

\section{UILIS D-Sonte}

This journal is operated by the University Library System of the University of Pittsburgh as part of its D-Scribe Digital Publishing Program, and is co-sponsored by the University of Pittsburgh Press 


\section{Statues Also Die}

\section{Pierre-Philippe Fraiture}

Warwick University

"African thinking," "African thought," and "African philosophy." These phrases are often used indiscriminately to refer to intellectual activities in and/or about Africa. This large field, which sits at the crossroads between analytic philosophy, continental thought, political philosophy and even linguistics is apparently limitless in its ability to submit the object "Africa" to a multiplicity of disciplinary approaches. This absence of limits has farreaching historical origins. Indeed it needs to be understood as a legacy of the period leading to African independence and to the context in which African philosophy emerged not so much as a discipline as a point of departure to think colonial strictures and the constraints of colonial modes of thinking. That the first (self-appointed) exponents of African philosophy were Westerners speaks volumes. Placide Tempels but also some of his predecessors such as Paul Radin (Primitive Man as Philosopher, 1927) and Vernon Brelsford (Primitive Philosophy, 1935) were the first scholars to envisage this extension of philosophy into the realm of the African "primitive." The material explored in this article - Statues Also Die (Marker, Resnais, and Cloquet), Bantu Philosophy (Tempels), The Cultural Unity of Negro Africa (Cheikh Anta Diop), and It For Others (Duncan Campbell) resonates with this initial gesture but also with the ambition on part of African philosophers such as VY Mudimbe to challenge the limits of a discipline shaped by late colonialism and then subsequently recaptured by ethnophilosophers. Statues Also Die is thus used here as a text to appraise the limitations of African philosophy at an early stage. The term "stage," however, is purely arbitrary and the work of African philosophers has since the 1950s often been absorbed by an effort to retrieve African philosophizing practices before, or away from, the colonial matrix. This activity has gained momentum and has been characterized by an ambition to excavate and identify figures and traditions that had hitherto remained unacknowledged: from Ptah-hotep in ancient Egypt (Obenga 1973, 1990) and North-African Church fathers such as Saint Augustine, Tertullian and Arnobius of Sicca (Mudimbe and Nkashama 1977), to "falsafa"-practising Islamic thinkers (Diagne 2008; Jeppie and Diagne 2008), from the Ethiopian tradition of Zera 
Yacob and Walda Heywat (Sumner 1976), to Anton-Wilhelm Amo, the Germany-trained but Ghana-born Enlightenment philosopher (Hountondji [1983] 1996).

Statues Also Die, while not a "text" about philosophy or African philosophy, is a documentary that provokes philosophical reflections. The main purpose of this essay is to interrogate the documentary so as to bring out this philosophical content. There is first the ontological question and the idea of a distinct African mode of "being," an argument that will be investigated via Sartre's emancipative examination of subjectivity and colonialism but also, and more substantially, through a focus on Placide Tempels' ethnophilosophy. Secondly, there is the epistemological issue. The documentary and the various positions that it adopts with regards to African art and culture is, from an epistemological perspective, close not only to Tempels' Bantu Philosophy but also to Cheikh Anta Diop's ideas about the uniqueness of African civilization in The Cultural Unity of Negro Africa. The significant point here is that these texts, however different they might be, all resulted from the same epistemological terrain and were also driven by an analogous ambition to define the contours of an authentically African cultural and aesthetic continuum. This terrain and set of pronouncements will be, in the later part of this study, examined by way of VY Mudimbe's essay "'Reprendre" (1991). Thirty years after African independence, Mudimbe, who, like Marcien Towa and Paulin Hountondji, has often adopted a critical stance towards ethnophilosophy, is able here to take stock and appraise the many responses generated by African art in the second part of the 20th Century. Mudimbe does not focus on Statues but his work is, however, able to reflect on the entanglements amongst African decolonization, ideology, and aesthetics. Alongside ontology and epistemology, aesthetics, which has since the Enlightenment been an important sub-discipline of European philosophy, is called upon to philosophize about African art and the evolving relationships between artworks and their "producers" in a "post-authenticity" Africa.

The essay is less about art per se than the way in which African art has been interrogated in the past sixty years. This emphasis on meta-discursive issues might, however, be a little misleading as it has the tendency to play down the documentary's immense aesthetic qualities. The fact remains that Statues is a strikingly intriguing and beautiful piece of work. It is, at the same time, "art" and "essay" and, as such, combines aesthetic creativity with an in-depth reflection on beauty. In It For Others (2013), Duncan Campbell, the Irish video artist, pays a direct tribute to Statues and its revolutionary dimension. Campbell seems to argue here that Sartre's and Fanon's ideas have retained their relevance in this era of late capitalism. The recent flurry of books and articles on Fanon is an interesting case in point. ${ }^{1}$ This activity is, however, more than just commemorative. Like Achille Mbembe in his Sortir de la grande nuit, Campbell suggests that late capitalism, in Africa, 
Europe, and Northern Ireland, is strangely reminiscent of late colonialism. Statues Also Die is called upon to comment on the world today and reopen the vexed issue of the relationship between art objects, their commodification and the value of images. In the past few years, Campbell has made a number of strikingly polemical documentaries such as Bernadette (2008), a piece focusing on Bernadette Devlin, the Irish socialist and republican political activist and dissident. Campbell's documentaries fall into the essay film genre, "a form that thinks" (Jean-Luc Godard, cited in Corrigan: 33). He has a tendency to rely on historical archives and newsreel footage to reconstruct the history of past events and figures but also reflect on the way in which these images are used by filmmakers to present and interpret reality. There is therefore an ambition to write stories but also to explore self-reflexively the conditions presiding over this construction. In a talk on It For Others that he delivered at a conference dedicated to Chris Marker (MIT, 2013), Campbell compares Sans Soleil - and particular Marker's examination of Amílcar Cabral - to his own take on history and historiography. ${ }^{2}$ In other interviews and lectures, Campbell argues that the documentary, as a genre, is highly constructed and relies on the same conventions and devices as fiction (plot, narrative voices, viewpoints) and that the footage incorporated and edited by filmmakers offer, ultimately, "no transparent window onto reality."3 Campbell's own treatment of such characters as Devlin and Joe McCann, the IRA fighter whose image appears briefly in It For Ohers, does not escape this inherent limitation of the genre. Regarding the making of Bernadette, Campbell says that he was seeking to understand what was made of her by the media whilst attempting to remain "faithful" to her character and what she stands for. ${ }^{4}$ This dual perspective the story but also the mechanisms and choices presiding over the genesis and development of the story - was also a central self-reflexive position adopted by the directors of Statues Also Die, a documentary as much about art as the art of film-making (Beugnet 2008).

\section{African Art and its Commodification}

Before appraising some of the responses engendered by the category "African art," I would like to focus on Statues Also Die which remained partly censored until 1968 (Chamarette: 2009; Cooper 2008: 12; Payot 2009: 13-14), less for its anti-colonial content than for featuring real characters such as François Mitterrand who appears briefly in the second part of the documentary in his capacity as Minister of France's Overseas Territories. Statues is both a documentary and an essay; an essayistic documentary or a cinematic essay. The documentary certainly falls into the "art et essai" genre. The difficulty, for the viewer, resides in the fact that images, some still and others "moving," are juxtaposed with a running commentary by Jean Négroni. The narrator pursues a thesis of sorts, and throughout this demonstration he provides a number of facts and arguments to substantiate 
his case. The premise of this demonstration is that "Negro art" (black art rather than African art) has remained a misunderstood object and that this large-scale misconstruction is the main factor behind its imminent death.

The word "object" is important and sums up some of the most pressing discussions marking this period of cultural and political emancipation. African art, it is argued, has no autonomy. Despite its variety and creativity, it has remained an object of consumption. Its status is defined by the onlooker who, more often than not, is ill-equipped to discern how and why African objects are first and foremost the products of time- and space-specific conditions of possibility. The argument has morbid overtones; from the very beginning of the documentary the viewers are made aware of this process of objectification which, it is suggested, will precipitate African art into oblivion.

This focus on the exotic reception of "negro" art and on its misunderstanding by the general public is utterly political. It resonates with other anti-colonial statements of the period, particularly those formulated in existentialist circles by figures such as Albert Memmi, Francis Jeanson and, of course, Frantz Fanon. It would not be an exaggeration to argue that postwar French anti-colonialism rhymes with existentialism and that the period was dominated by figures close to the many outlets - Présence Africaine but also Esprit and Les Temps modernes - through which anti-colonial ideas were disseminated. Jean-Paul Sartre was of course the main spokesperson of this phenomenology-inspired brand of anti-colonialism. Already in Being and Nothingness (1943), he had analysed the difficulty of "being" and contended that inter-subjective relationships always imply a degree of objectification. By the same token, Marker deplores that these "negro" artefacts have been cannibalized by Western audiences and have become inauthentic objects constrained, ultimately, to perform an act they were not meant to be performing. Interestingly, it can be argued that it is the "inauthentic" that makes it possible to think the instantiation, representation and ipseity of that which is presumed to be "authentic."

The documentary is thus predicated on the idea that museums - the Musée de l'homme, the Museum of the Belgian Congo in Tervuren, the British Museum and the Pitt River museum in Oxford ${ }^{5}$ - are places of deceitful and inauthentic exhibits. This point of view, which was not completely new in 1953, needs to be understood against the backdrop of debates on the aesthetic status of "primitive" objects. In his Primitivism in Modern Art (1938), Robert Goldwater reflects on recent developments in the organization of ethnographic museums and is keen to identify, in the work of museum curators, an increasing tendency to present "their objects (or at least some of them) as worthy of purely formal study" (Goldwater: 13). This sporadic shift from function to aesthetics is for Goldwater "the 'ethnocentric' risk" (Goldwater: 13) facing museums of ethnology in the interwar period. But he is also eager to argue that this "ethnocentric risk" has beneficial 
consequences: "Thus - he concludes- the artistic creations of primitive cultures have entered fully into the world history of art, to be, like those of any other culture, understood and appreciated on their own merits" (Goldwater: 13, my emphasis).

\section{“Forces” and “Life”}

In their critique of museums, Resnais and Marker challenge the idea that African artefacts have been at all appraised on their own merits. There is on the part of the two directors an ambition to remedy the situation and offer a more reliable explicatory reading grid. They adopt here the part philosophical, part ethnographic model developed by the Franciscan missionary Placide Tempels in Bantu Philosophy (1959 [1949]). This famous book constitutes an important milestone in the history of writing on Africa. It is the first-ever book to be published by Présence Africaine and its reputation owes a great deal to Alioune Diop's celebratory preface. Bantu Philosophy is presented here as the most influential statement on Africa alongside Sartre's "Black Orpheus." Alioune Diop adopts a discourse of difference. He argues that Africans and Europeans do not share the same worldview. He highlights Europe's ethnocentric self-obsession and inability to know itself other than through "the prism of its own consciousness." 6 Africans, on the other hand, are said to possess an "innate respect of man and creation" and to be the representatives of a type of humanism in which man is at one with the world and with "life." This preface is thus an opportunity to come to terms with past and present inequalities and to envisage the construction of what Alioune Diop calls "the communal city of tomorrow." In this reflection, which, it must be said, remains general and certainly very conciliatory, Alioune Diop opposes the "will to power" responsible for Nazi atrocities and colonial crimes, to the African "vital force" (A. Diop 1949).

I would like now to focus briefly on Placide Tempels' essay in order to read it alongside Statues and thus assess the way in which Resnais and Marker embraced a loosely "tempelsian" conception of African art. Placide Tempels was a Flemish missionary who, from the 1930s onwards, worked as a teacher and an evangelist among the Luba people of southern Katanga (Belgian Congo). Like many missionaries and colonial administrators, he became a keen ethnographer. This scientific activity was of course conducted in the name of the civilizing and evangelizing mission. Beyond its obvious patronizing tendencies, Bantu Philosophy is also a book that bore witness and contributed to the post-war decolonization of knowledge on Africa. It also presents itself as a response to earlier statements and is the admission, on the part of Tempels, that the Church needs to review its evangelizing practices. Indeed, the book challenges some prevailing prejudices regarding sub-Saharan traditions: 
It is contended that in condemning the whole gamut of their supposed "childish and savage customs" by judgment "this is stupid and bad," we have taken our share of the responsibility for having killed "the man" in the Bantu (Tempels: 20).

If Tempels continues to use contentious words such as "primitive" and "non-civilized," he is determined, however, to demonstrate that Bantu ontology is underpinned by a set of coherently articulated principles. The Bantu worldview rests, according to Tempels, on the concept of "vital force":

The Bantu say, in respect of a number of strange practices in which we see neither rime nor reason, that their purpose is to acquire life, strength, or vital force to live strongly, that they are to make life stronger, or to assure that force shall remain perpetually in one's posterity.[...] Force, the potent life, vital energy are the object of prayers and invocations to God [whom the Bantu designate] as "the Stong One," he who possesses Force in himself [...]. Supreme happiness, the only kind of blessing, is, to the Bantu, to possess the greatest vital force [...]. Every illness, wound or disappointment $[\ldots]$, every injustice and every failure : all these are held to be [...] a diminution of vital force (Tempels: 44-46, emphasis in original).

This all-encompassing principle regulates daily life, but also the afterlife, and provides a hierarchical framework in which the Bantu is situated within a chain of forces and tied up in a relation of reciprocal influences. God and the ancestors stand at the upper end of the chain, then the living Bantus, and, at the inferior echelons, animals and inanimate things. In his commentary Marker also endeavours to translate this sense of reciprocity between the world of the dead and the world of the living. Resnais and Marker are of the view that this vital force, and particularly its ability to reconcile life and death and act as a mediating principle between men, animals and things, is the main societal, religious, and cultural factor behind African artistic production. Indeed, there is a tendency to collapse traditional categories and to argue that religion and art are in Africa entirely interchangeable. In a world where "everything is linked to religion" and "everything is linked to art" (Marker 2010: 28), the divide between the cultual and the cultural is presented as irrelevant and as a distinction which has no validity in the African worldview. Africa, as it is understood by Resnais and Marker, does not suffer any deviation. In an extraordinarily fast-paced scene this unity is exemplified by the juxtaposition of objects made from different substances (wood, stone, and materials). The repetition of similar geometrical patterns implies that they all result from the same fabric in which inanimate objects, animals, men, and the earth are one and the same thing. This pure realm of transitive relations is close to Tempels' own unanimist understanding of the Bantu worldview constituted of "precise, well-defined ideas fitting into a logical system" (Tempels: 41). By 
contrast, European presence in Africa "is understood to rip this fabric" (Cooper: 14) and there is no doubt that the frantic accumulation of images, coupled with Guy Bernard's equally frenetic musical score, adds to the inherent violence of this scene.

This world of rigour - in which nature and human creations replicate the gestures of the gods - was evidently not fully thought and systematized by Resnais and Marker. They adhere to a Tempelsian reading grid even though it is doubtful that they ever read Bantu Philosophy. When they were first approached by Alioune Diop to make this documentary (Le Garrec $\mathcal{E}$ Vautier: 35), 7 the two French directors knew nothing about African art (Martinez-Jacquet: 18). For this reason, they were advised throughout the process by the well-known art critic Charles Ratton who selected the 135 pieces shown in the documentary. Ratton was close to Alioune Diop and had just contributed, alongside experts such as Georges Balandier, Jacques Howlett, William Fagg, and Marcel Griaule, to a special issue of the journal Présence Africaine dedicated to African art (Balandier \& Howlett 2010 [1951]). Resnais and Marker were therefore influenced by the arguments put forward by these specialists who had also welcomed Tempels' explicatory model, relied on his understanding of the vital force, and attempted to identify an aesthetic "grammar" common to all artistic productions from black Africa.

The documentary sets out to reveal the unitary characteristics of African art (in the singular). Resnais and Marker are completely committed to this project, which, in the early 1950s, had very obvious political, and panAfricanist, connotations, if not implications. What is African art? What is African culture? are the questions that they address here. On closer inspection, however, one realizes that these questions cannot be disentangled from the colonial situation. The short answer the documentary provides to these questions is that African culture is essentially something that European culture is not. One can thus conclude that the discourse of difference promoted by the documentary contributes to envisaging the emergence of a post-colonial geopolitical order in which Africa will be entitled to assert and cultivate its cultural specificity (authenticity). Resnais and Marker bemoan the effects of European/colonial modernity on African art. They also mention the disastrous impact of capitalism on African artists and the emergence of what they disdainfully refer to as "bazaar art" and "indigenous craft" (Marker 2010: 31). There is also a sense that the agony of Negro art has been accelerated by unfortunate attempts on the part of African and European artists to fuse their respective aesthetics. This "métissage," argues Marker, means that "both traditions will destroy each other" (Marker 2010: 32).

Beyond this condemnation, the French directors are of the view that revolutionary art (Marker 2010: 32) will not foster any anti-colonial cause. The anti-colonialism of Marker and Resnais is rooted in a stable and 
immutable definition of African culture and art. Unlike Sartre, they implicitly argue that African creators must remain what they are and that their survival will depend on their ability to express their essential Africanness. This central thesis, as will be now explored, is also to be found in Cheikh Anta Diop's The Cultural Unity of Negro Africa (1962 [1959]).

\section{Africa's Difference}

C.A. Diop's essay is a militant text in which the respective features of distinct cultures, or "cradles" (with Northern and Southern cradles used as shortcuts for Europe and Africa), are appraised and, ultimately, opposed in the logic of this discourse of difference already identified in Alioune Diop's writings and in Statues. Like Tempels, he is determined to provide a set of general statements on the unity of Africa; and, what is more, to trace the origins of this African unity in ancient Egypt. Political power, and in this specific example the choice of African kings, is explained by way of a "tempelsian" grid:

The choice of the African, whether he was ancient Egyptian, Ethiopian or came from another part of Africa particularly the Bantu, was linked to the idea he had of the world of beings and of essences; thus to a whole ontology and metaphysics which the R.E. Tempels calls "Bantu Philosophy." The whole universe is divided up into a series of beings, of quantitatively different forces, which are thus also qualitatively different. From this is derived a hierarchy or natural order. Each of these pieces of essences, of ontological beings, appears to us in the guise of a material body, either animated or inorganic. These forces, said to be vital forces, are additive, that is to say, that if I carry on me in the form of talisman, amulet, fetish - call it what you will - the organ where the vital force of an animal is supposed to be fixed (claw or tooth of lion for example), I add this force to mine (C.A. Diop: 152).

This essay is also underpinned by a pan-Africanist agenda and the ambition to identify the homogeneity of African culture. C.A. Diop contends that a shared sense of historical continuity is indispensable "to the idea of a multinational African state" (C.A. Diop: 10). The ideological basis of the book is synonymous with this search for common traits which Africans would be able to recognize but also celebrate, and be recognized for, that is to say their Africanness. Although written by a convinced anti-colonial militant, The Cultural Unity of Negro Africa remains haunted by Diop's French university mentors. Indeed, Diop pays tribute here to Marcel Griaule, Gaston Bachelard and his professors, André Aymard and André LeroiGourhan (C.A. Diop: 7). In this sense, C.A. Diop's essay is very close to Statues, a text advocating African liberation by means of Western scholarship and expertise. C.A. Diop's comparative analysis of European and African cultural "cradles" is heavily dependent on the "colonial 
library," in VY Mudimbe's meaning of the phrase. C.A. Diop's tour de force lies in his ability to extract, from this Western corpus, a body of arguments to substantiate the thesis of a radically different Africa and, what is more, put forward the claim of a superior African Ur-civilization whose main traits are still prevalent today but are increasingly threatened by the Westernization of Africa. This interpretative process is not, however, without its many ideological pirouettes (see Howe: 180).

In this book, C.A. Diop uses family structures and kinship as points of departure to evidence the cultural homogeneity of Africa and trace the fundamental difference between the northern and southern "cradles." This premise enables him to take to task European gender politics and argue that Africa has, since ancient Egypt, been a place of greater equality, a point which resonates with Marker's insistence on African unanimism. In this demonstration, C.A. Diop relies on the opposition between matriarchy and patriarchy. By way of established French historians and classicists such as Fustel de Coulanges and Victor Bérard, he is able to mount a case against patriarchal societies and, conversely, sing the praise of matriarchal structures in Africa. Via the examples of Osiris, and Dionysus (his Greek Doppelganger), C.A. Diop surmises that matriarchy has generated more egalitarian gender relations and that this historical difference is still palpable in Africa now (C.A. Diop: 166). By contrast, he posits that women in the Northern cradle have remained victims of the patriarchal system. His depiction of this other "Indo-European" (or "Aryan" as he calls it) model is completely dualistic and appears as a foil to celebrate African cultural achievement since Egyptian antiquity.

Like Marker, and Tempels before him, C.A. Diop is keen to equate Africa with life and vitality and to highlight the sacred role assumed by mothers and fecundity in the African worldview (C.A. Diop: 36). ${ }^{8}$ In his conculsion, Diop return to the foundational role of matriarchy and to the opposition between the two cradles:

[T]he Meridional cradle, confined to the African continent in particular, is characterised by the matriarchal family, the creation of the territorial state, in contrast to the Aryan city-state, the emancipation of women in domestic life, xenophilia, cosmopolitism, a sort of social collectivism [...], a material solidarity of right for each individual, which makes moral or material misery unknown to the present day; there are people living in poverty but no one feels alone and no one is in distress. [...] The Northern cradle [...] is characterised by the patriarchal family, by the city-state [...]; it is easily seen that it is on contact with the Southern world that the Northerners broadened their conception of the state [...]. The particular character of these citystates, outside of which a man was an outlaw, developed an internal patriotism, as well as xenophobia. Individualism, moral 
and material solitude, a disgust for existence [...]. An ideal of war, violence, crime and conquests [...](C.A. Diop: 197).

Further, Diop engages in a meditation on the future of the planet earth in the cosmos. He moves away from the cultural and anthropological issues explored in the essay (matriarchy vs. patriarchy) to reflect on the way in which science and scholarship could be mobilized to contribute to "the future of the species" (C.A. Diop: 198). This proto-ecological rumination provides C.A. Diop with yet another opportunity to praise Africa and to oppose what he regards as its innate vitalism to the morbid destructiveness of the West. African scholars, he contends, are better placed than any others to undertake this planet-saving exercise. Their "cultural past" predisposes them to this formidable task and Diop concludes triumphantly (in what is the last sentence of the book) that "the universe of tomorrow will in all probability be imbued with African optimism" (C.A. Diop: 199).

The tone of this concluding statement, in which one can detect a high degree of wishful thinking, is a recurring rhetorical trait of essays on African decolonization in the immediate post-war era but also after (Sartre 1948; Fanon 1961; Mudimbe 1988; Mbembe 2010). In Statues, the narrator concludes his commentary with the idea that blacks and whites will be the architects of humanity's future, "notre avenir" (Marker 2010: 32). C.A. Diop's happy ending, in which Africa is rehabilitated and given a leading role in the reconstruction of the "universe of tomorrow," is the expression of his anti-colonialism and willingness to read African history away from colonial scholarship. The paradox, however, is that this political and epistemological gesture remains heavily dependent on nineteenth and early twentieth century conditions of possibility: if he demands independence, he is often unable to depart from the tenets that had characterized late nineteenth-century Africanism.

C.A. Diop believes that the unity of African culture is the product of geographical and historical conditions, that this homogeneity was established in a very distant past (Ancient Egypt), and maintained, albeit precariously, throughout the ages until the 20th Century. This premise, which is shared by the authors of Statues, does not easily integrate ideas of change, evolution, and transformation. The terminology used by C.A. Diop to refer to the stability (or otherwise) of the original "cradles" bears witness to his anxiety to preserve what is nonetheless continually exposed to cultural erosion. By and large, C.A. Diop's interpretative methodology remains dualistic and redolent of diffusionist theses (Tylor 1958 [1871]).

In his exploration of the development of the human and social sciences from the Classical age to the modern period, Michel Foucault identified a turning point or epistemological shift at the beginning of the twentieth century, a moment coinciding with the emergence and the methodological constitution of linguistics, ethnography, and psychoanalysis. Indeed, in the 
last chapter of The Order of Things, Foucault argues that social scientists are increasingly inclined to accommodate deviations and to move away from a tendency which consisted in treating social, and human phenomena from a dualistic perspective. Henceforth, it became gradually unacceptable to approach these phenomena on the assumption that what was not "normal" within a given system was necessarily "abnormal." In this process, which was to transform the human sciences and generate a decisive break with evolutionist and diffusionist practices, Foucault singles out Freud who was "the first to undertake the radical erasure of the division between the positive and the negative (between the normal and the pathological, the comprehensive and the incommunicable, the significant and the nonsignificant)" (Foucault: 393). It seems that C.A. Diop, despite the epistemological novelty of his reading of African historiography (and his ambition to restore some obfuscated aspect of African history), cannot quite escape previous dichotomies. His obsession with original cultural "cradles" remains deeply dependent on a set of ideas that had been mobilized to legitimize the colonial order, a system of knowledge largely predicated on centres and peripheries. In The Invention of Africa, a book which relies extensively on The Order of Things, Mudimbe contends that C.A. Diop was located at the crossroads between a new knowledge about Africa and the "colonial library" and that, as such, his work constituted the best but also one of the most excessive examples of the "Africanization of diffusionism" (Mudimbe 1988: 181).

Ultimately, C.A. Diop's promotion of a pure and more original cradle and Marker's rejection of "métissage" in Statues Also Die result from the basic idea that Africans are first and foremost the members of a rigorously constituted whole. Indeed, Marker regrets that a willingness on the part of the Church to foster syncretism in Africa has divested Christendom of its aesthetic signature. In a particular scene, the camera's rapid focus on the façade of Dakar's Cathedral Notre Dame des Victoires and its three African angels is accompanied by a dismissal of Negro-Christian art:

Everything contributes to the downfall of Negro art. Caught between Islam, the enemy of images, and Christianity, which burns idols, African culture collapses. In order to rescue it, the Church attempts a métissage: Black Christian art. But each of the two influences destroys the other one (Marker 2010: 31-32; translation adapted from subtitles)

Statues and C.A. Diop's essay are, as argued earlier, not philosophical texts but their examination of sub-Saharan Africa lends itself to a philosophical discussion. There is first the epistemological issue and the fact that their authors' style remains dependent on a specific order of knowledge and on their own inability to extricate themselves from explanatory grids in which Africa (its arts, culture, and history) remains the West's "Other." This discourse of difference would, during decolonization and after, play an 
important role in the development of Présence Africaine and its "Politics of Otherness," to use VY Mudimbe's phrase in The Surreptitious Speech. If this discourse provided the basis for autonomy and the emergence of a distinctive African literary agenda in French (and in English), it also generated virulent responses from professional African philosophers. Indeed, in the context of the increasing professionalization of the discipline among Africans, Tempels's posture - and statements by those intellectuals loosely supportive of his exploration of African singularity (A. Diop, C.A. Diop, and Marker would fall in this category) - became anathema from the mid-1960s onward in works by thinkers such as Paulin Hountondji, Marcien Towa, and VYMudimbe, on whom I shall focus now. The move from Tempels/C.A. Diop to Mudimbe is less abrupt than it may seem. Mudimbe belongs to a generation of African philosophers who built their intellectual credibility on a rejection of ethnophilosophy and negritude and his reading of African art is predominantly based on the rehabilitation of individual artists. ${ }^{9}$ Interestingly, however, there has been in the last 15 years a more sympathetic reappraisal of ethnophilosophy by contemporary African philosophers (see Bidima 2011 and S. B. Diagne 2011), aestheticians (Daniel Payot 2009) and even artists operating well beyond Africa, the Irish video artist Duncan Campbell being, as I shall argue at the very end of this essay, a particular case in point.

\section{Traditions and Reprises}

Let us examine Mudimbe's response to the philosophical and, above all, aesthetic context that marked the emergence of Présence Africaine. In his analysis of the colonial library, the Congolese thinker has demonstrated that Africa remained for centuries an object of fascination that Westerners would invariably appropriate to satisfy self-aggrandizing ambitions. In this process, Africa became a mere receptacle that they would fill with their own ideas at the same time as they would divest it of its contents and values. Mudimbe has also dedicated a number of essays to contemporary African art (Mudimbe 1991; Mudimbe 2016: 200-216) ${ }^{10}$ and the place of Africa in European art and architecture in the Middle Ages (Mudimbe 1973: 25-31; Mudimbe 2016: 183-189), the Renaissance and the Classical Age (Mudimbe 1988: 5-10), and the modernist era (Mudimbe 1994: 55-70; Mudimbe 2016: 190-199). In these texts, he appraises artistic trends, links them to prevailing racial discourses, and identifies a number of invariables but also epistemological shifts. Although Mudimbe never specifically focused on Statues Also Die, he has nonetheless abundantly commented on the discourse of difference that I have identified in this documentary.

In "'Reprendre.' Enunciations and Strategies in Contemporary African Arts" (1991), Mudimbe explores the significance of Pierre Romain-Desfossés, a former French colonial officer who moved to Élisabethville (now 
Lubumbashi, DRC) in 1946 where he founded "Le Hangar," an art studio (Mudimbe 1991: 277). Romain-Desfossés became an important local figure and was a key promoter of what could be called a re-indigenization of Katangese artistic imagination. Mudimbe is keen to highlight the patronizing dimension of his enterprise. Like Tempels at the same time, Romain-Desfossés regarded himself as a benevolent and supportive "father" who would guide his "black children" (Mudimbe 1991: 279) and help them to retrieve and express the essential traits of an innately African aesthetic tradition. Mudimbe goes on to explain that Romain-Desfossés's mentoring of local budding talent was predicated on a system in which Africa and the West were treated in radically oppositional terms. Indeed, he took it upon himself to protect his pupils from "Western degeneracy," "snobism," and "folly" in order to enable them to tap into the "pure and fresh sources" of their African creativity (Mudimbe 1991: 278). The dualism at work here echoes what has already been identified in Tempels's essay, Statues, and C.A. Diop's impassioned rehabilitation of Africa. The vocabulary used by Romain-Desfossés reiterates the morbid status of the West, the degeneracy at the heart of its artistic practices and, it is implied, its imminent fall. Africa, on the other hand, is praised for its vitality and life-giving propensity. Mudimbe exposes the nature of Romain-Desfossés's cultural analysis and the latter's view that his African "pupils" are the recipients of a collectively shared "Nilotic" creativity (Mudimbe 1991: 277). We are in 1946 and there is no doubt that this concern with Egypt as a "source" from which a major civilization was diffused throughout Africa resonates with C.A. Diop's exploration of "cradles." Understandably, Mudimbe is critical of RomainDesfossés's position and his ambition to link "geography, race, and art" (Mudimbe 1991: 277). His endorsement of an ethnically based "aesthetic unconscious, common to sub-Saharan Africans" (Mudimbe 1991: 278) does not sit comfortably with Mudimbe's promotion of existential freedom and authenticity (in the Satrean meaning of the word). Already in his very first essays, he had complained about this precedence that had been fostered by ethnophilosophy but, more problematically, had also become one of the most visible ideological tenets of the Mobutu-driven return to Bantu authenticity (Mudimbe 1968). For Mudimbe, ethnophilosophy is a critical vein that served an emancipating purpose at a particular time in history even though, elsewhere in his work, he has remained very dismissive of its subsequent transformations and instrumentalizations by African rulers and African American activists. ${ }^{11}$ In "'Reprendre," he adopts a similar position: if he praises (with some caveats) Romain-Desfossés's activities in colonial Katanga, he nonetheless believes that his model and his focus on tradition are of little use for understanding the evolution of African art after independence.

This examination of Romain-Desfossés, who feared that Negro art would die out if not protected from decadent European influences, lends itself almost as an indirect commentary by Mudimbe on Statues and the 
period that bore witness to the release of the documentary. Like RomainDesfossés and many others of his contemporaries, Marker is unable to entertain the view that Negro art might survive the aesthetic upheaval usually associated with the large-scale Westernization of Africa. In "'Reprendre,'" Mudimbe proves them wrong and demonstrates, with the benefit of hindsight (this must be stressed), that African art was to be produced against a less dualistic set of paradigms. Reprendre, the French verb that Mudimbe leaves untranslated, conveys the simple idea that African artistic creativity was affected by European practices but that African art did not disappear as a result. The verb reprendre - an equivocal verb meaning to take up again, take over, but also reprise and re-appraise according to the context - is used here by Mudimbe to disrupt the rigid historicity (pre-colonial, colonial, post-colonial) that for a very long time prevailed among scholars of European imperialism and art historians. Mudimbe argues against this type of chronological segmentation and contends that the racially compartmentalized colonial context was, in fact, more porous than it may have seemed and generated a space in which African and European traditions would be taken up again and submitted to deliberate processes of reprises, re-appraisals, and reprisals. Marker was unable to see the future of African art as his attention remained understandably focused on the excesses of late imperialism. Statues is a documentary on art but art in the 1950s, particularly African art, was a category that remained entirely entangled in political and racial issues (Payot: 14). In his critical examination of African postcolonial art, Mudimbe does not move away from these issues but he contends that the less than palatable consequences of late colonialism, such as, for instance, the mass production of indigenous artefacts, ironically generated a space where African artists were able to thrive and invent new rules beyond the strict opposition between African and Western traditions.

Unlike Marker, who speaks on behalf of Negro art (in the singular) and glosses over regional singularities (even though the documentary shows 135 objects from more than ten different countries), Mudimbe is eager to highlight the obvious but often overlooked fact that African art is "amazingly diverse" (Mudimbe 1991: 277). Mudimbe, however, goes a step further as he also explores the works of individual contemporary artists such as Twins Seven Seven (Nigeria), Iba N'Diaye (Senegal), or Tshibumba Kanda-Matulu (DRC), the Congolese artist to whom Johannes Fabian (1996) dedicated a book in which the artist is presented as the unofficial historiographer of Congo-Zaire. This focus on individual production is, on Mudimbe's part, yet another sign of his effort to explore these artists' authenticity (in the Sartrean meaning of the word). For Marker, on the other hand, art production is an immanent feature of Africanness. It is a pervasive aspect of African "vital force" and "being" (in Tempels's understanding of the concepts) but is, however, not interrogated by African practitioners. This view reiterates Tempels's idea that, although there is such a thing as African 
(or Bantu) philosophy, its main agents are unaware of its inner mechanisms and thought procedures (Tempels: 21). African art is therefore a domain without aestheticians, a point, which, ultimately, does little to affirm its autonomy since it is presented as the by-product of an "already-there" and the concrete manifestation of a universally accepted set of values in which the notion of "man" will be eternally subsumed by that of the community.

Mudimbe's focus on contemporary African artists and their tendency to reprendre traditions, often ironically, is useful because it helps us to measure a very noticeable transformation in the way in which African art has been received outside of Africa but also, and more importantly, perceived by its own practitioners since the early 1950s. His focus on "popular art" is in this respect particularly revealing of a domain in which a rich variety of styles, registers, and genres interact and interfere with one another. "Popular art," as a phrase, is eminently linked to the development of the Western market economy. It also blurs the divide between the artistic and the consumable. It threatens the sacrosanct status of "Art" and, since everything seems to be reproducible (as Marker bemoans in Statues), brings into question notions usually cherished by art historians: the genius of the artist and the uniqueness of his/her inspiration. Mudimbe welcomes the emergence of African popular art. If it often lacks is in his view the "polysemous, associative, [and] open principles of most works of art" (Mudimbe 1991: 283), he is eager to signal the complexity of artists such as Tshibumba Kanda-Matulu.

Mudimbe's notion of "'Reprendre" sheds light on the legacy of Présence Africaine and on the ethnophilosophical pronouncements of some of its major figures (Placide Tempels, Alioune Diop and Cheikh Anta Diop) but also more distant supporters (Pierre Romain-Desfossés, Alain Resnais, and Chris Marker). It also provides a retrospective refutation of the discourse of difference highlighted in this article. The emancipative trajectory from "Negro art" to the constitution of home-grown African discourses on art resonates with Mudimbe's optimistic concluding remark in The Invention of Africa:

I believe that the geography of African gnosis also points out the passion of a subject-object who refuses to vanish. He or she has gone from the situation in which he or she was perceived as a simple functional object to the freedom of thinking of himself or herself as the starting point of an absolute discourse. (Mudimbe 1988: 200)

\section{From Statues Also Die to It For Others}

Statues Also Die celebrates the greatness of Negro art but announces its imminent death. In their dismissal of "métissage" and failure to ascribe a 
revolutionary potential to non-traditional African art, the French directors signal their inability to identify evidence of a possible renaissance in African artistic practices of the early 1950s. Their perspective, as suggested here, bears witness to the intellectual debates in ethnographic and anti-colonial circles of the period. The documentary, however, provides more than it promises and does not - which is very fortunate - completely adhere to its program of ethnographic orthodoxy and cultural authenticity. By skillfully combining slow moving scenes with frantically paced shots and newsreel footage, the directors are able to instill vitality into these mortal statues: "The animation of the inanimate is key to the life that this documentary breathes back into its subject, while it also resuscitates links to African culture" (Cooper: 13). The post mortem becomes paradoxically a pretext to submit these authentic artefacts to a process of cinematic reprise.

The recent release of It for Others (2013) by the Irish video artist Duncan Campbell provides an interesting addendum to the long-term legacy of Statues and its underlying anti-colonial commentary. This 54 minute essay film won its director the 2014 Turner Prize. It deliberately reconnects with Statues and problematizes the relationship between art and its consumers, between objects and the predatory "gaze" of viewers/purchasers. The scope of the film is wide and avowedly militant. Campbell's discussion on the value of the object - the "it" of the title whose only purpose is to be "for others" - is underpinned by explicit references to Capital and Marxist economic theories and mediated by way of a choreographed equation "Measure of value" /"Means of circulation" - performed by ballet dancers from the Michael Clark's company dressed in black and moving on a white canvas. Another powerful equivalence is established between the commercialization of goods and ideas and the commodification of significant historical moments such as the anti-imperialist IRA martyrdom notably the recent use of Joe McCann's image on Christmas stockings - and the equally ironic focus on a Chinese sweatshop mass-producing tees-shirts at the effigy of Che Guevara. The interesting point, however, is that It for Others is itself an artistic by-product - a reprise and re-appraisal - of Statues Also Die. Campbell pays tribute to its aesthetic and political power and the first part of the film is a remake of the French original. There are, however, subtle differences. The narrative style adopted by the female voiceover is less stilted, less solemn, and declamatory than Négroni's. In fact, the tone and rhythm of the exposition is close to that of Sans Soleil. There is a tendency in Statues to provide comprehensive explanations so as to equip the viewers with the tools to grasp what African art is and is not. This didactic dimension is not absent from It For Others but here the narrator is more interested in deciphering the choices and decisions presiding over the composition of the documentary. This explicatory work focuses as much on the film itself as on what the film is overtly exploring (art, the value of art objects, and the language of advertising) as if the narrator had constantly to remind the viewers but above all herself of the purpose and focus of the 
documentary: "An educational and methodological film on the characteristics of commodities in relation to value when put into circulation." 12 This running commentary espouses the structure of a travel$\log$. Indeed, the narrator structures her commentary as a sequence of diary entries ("March 14," etc.) to report on the development of the documentary which is treated as work in progress rather than as a completed piece, a point reflecting Campbell's ambition to produce "open-ended" films. ${ }^{13}$

The narrator provides also a number of pointers to describe, to what is obviously a non-Francophone audience, the context in which Statues was produced in 1953, at a time (a point forcefully made here) when France was waging a war in colonial Indochina. In the second part of the film, there is an extraordinary sequence capturing Campbell's ambition to explore and parody the processes underpinning the dissemination of facts and information by the media. A cardboard box of Unifilla $($ appears on the screen and becomes a radio as an aerial is conspicuously emerging form one of its corners. At the same time, a female voice comes out of the radio set and starts praising the revitalizing benefits of a Scotch Whiskey-flavored shampoo. Rather incongruously - Campbell relishes such incongruities - the focus shifts to current affairs and to what a new male radio presenter describes as a number of bloody "manifestations musulmanes" (Muslim demonstrations) that have taken place in Algeria. It becomes apparent that this authentic news bulletin was broadcast in June 1961 as the journalist subsequently refers to the condemnation of Georges Robin, one of the French army officers who took part in the OAS-orchestrated putsch against the French colonial administration in Algiers on 22 April 1961.

By way of these diegetic and non-diegetic commentaries, the viewers are in a position to glean relevant information on the history of French colonialism and its gradual demise after the Second World War. In the first part of the documentary, the female narrator mentions the work of Frantz Fanon and focuses on the significance of Présence Africaine and, whilst African artefacts are displayed on the screen, she reads from Sartre's "Black Orpheus" and draws the spectators' attention to the notion of "anti-racist racism" to reinforce the curatorial violence that Marker and Resnais were denouncing in their documentary. She also conveys the content of a report published in 1971 by the journal Présence Africaine exploring the creeping effects of neo-colonialism in West Africa and elsewhere on the continent. ${ }^{14}$ She reflects on colonial and neo-colonial assimilation and regrets that some African regimes were built on ideas developed elsewhere by thinkers such as Locke, Voltaire and Montesquieu and that this intellectual dependency has precipitated the disappearance of cultural and linguistic diversity. She then establishes an analogy between this assimilation of Africa to that of African objects in Western museums. At this point, the film becomes selfreferential and concerned with the conditions of its own making. The viewer is informed that Neil MacGregor, the British Museum's director, denied 
Campbell and his crew access to some of the Beninese sculptures appearing in Statues Also Die and that they had originally planned to include in their film. This overt criticism of the British Museum's inability to recognize the validity of Campbell's project forms the basis of another related discussion on the status of African artworks in the postcolonial world. The narrator, who seems here to be speaking on behalf of Campbell himself, implies that the filmmaker had to rely on replicas, reproductions and serially produced masks to complete this particular section of the film. This limited access to originals, and the subsequent proliferation of copies, resonates also with the situation in which postcolonial subjects find themselves with regards to objects which were once their own, then were looted by colonial powers, and have been since curated by museums in major Western cities. In this respect, it is interesting to point out that all the 135 objects shown in Statues had been lent by private collectors and museums in the West. Exactly sixty years after, Campbell suggests that issues of their acquisition and repatriation have not been resolved yet. By linking the past to the present and suggesting that African art, and by extension Africa, has remained the West's "being-for-others" (Sartre), Campbell argues that the criticism at the heart of Statues has retained some of its relevance today.

\section{Conclusion}

This article has examined the nature but also the long-term legacy of Statues Also Die. This essay documentary was released at a time when oldstyle Africanism was reconsidering its premises and thought procedures in addition to reappraising the limits - the boundaries but also the limitations of its own investigative methodology. Statues is an intriguing object because it advocates freedom but remains nonetheless prescriptive. It embraces wholeheartedly a Sartrean understanding of objectification - intersubjective, racial, and, by analogy "curatorial" objectification; but it is also underpinned by a constraining interpretative grid in which African statues are presented as the products of a rigorously ordered cultural (and cultual) universe. This contradictory gesture has its logic and bears witness to a time - the ethnophilosophical moment of African thinking - when issues of political, economic, racial, aesthetic, and literary emancipation were inherently linked to claims of ontological definitions. In the Francophone domain, Présence Africaine (the publisher and the eponymous journal) came to represent this moment. Its main quest - what is Africa? - was approached from a number of different disciplines. Tempels' Bantu Philosophy and C.A. Diop's The Cultural Unity of Negro Africa exemplify this ambition to explore Africa from the point of view of its purported ontological and cultural singularity. In "'Reprendre,'" Mudimbe dissects some of the ideological prejudices underlying the ethnophilosophical moment and, via Pierre Romain-Desfossé, focuses specifically on the aesthetic implications of this invented Africa. In his reading of recent African aesthetic trends, Mudimbe 
mobilizes an impressive array of secondary sources on African art and focuses on the conditions that facilitated its gradual absorption into Western aesthetic and curatorial practices. Beyond the subtlety of the analysis, Mudimbe's argument is driven by an ambition to reveal the romantic tenets upon which ethnophilosophical aesthetics was developed. Quite pragmatically, he concludes that African creativity is not immune to external pressure or rather, and more to the point, that external pressure and influence are not necessarily to be equated with the assimilation or the "death" of the "original" creative impetus. African art, Mudimbe contends, has been for centuries actively engaged in a global process where "tradition," whilst still a very significant factor in contemporary productions, has also been contested, popularized, parodied and reprised. It For Others takes up again and reopens the issue regarding African art and its value, be it aesthetic or commercial. What is noteworthy here is the tribute paid by Campbell to emancipative demands resulting from Statues. Like Marker, he is very clear that issues of reception and spectatorship cannot be disentangled from politics and power relationships engendered by the violent confrontation of unequal market actors. Sartre, Fanon are briefly mentioned here to engage with a reflection on colonial alienation and the reification of the colonized and, much more fundamentally, the production of incongruous equivalences whereby the limits between objects and humans are perpetually suspended. 


\section{Bibliography}

Actuel Marx (2014), "Fanon," 55.

Balandier, G. and J. Howlett, eds. L'Art nègre (Paris: Présence Africaine, 2010)

Beugnet, Martine. "Du Film d'art à l'art du film: Les Statues meurent aussi de Chris Marker et Alain Resnais," CinémAction, 122 (2007): 39-47.

Bidima, J.-G. (1997), L'Art négro-africain (Paris: Presses Universitaires de France 'Que Sais-je,' 1997)

- - - - , "Philosophies, démocraties et pratiques: à la recherché d'un universalisme 'lateral'," Critique, LXVII (2011): 672-686.

Brelsford, Vernon, Primitive Philosophy (London: John Bale, Sons \& Danielsson, LTD, 1935)

Campbell, D. (2013), It for Others.

Chamarette, Jenny, Les Statues meurent aussi/Statues Also Die, http://sensesofcinema.com/2009/cteq/les-statues-meurent-aussi/] [accessed on 27 July 2015]

Cooper, S., Chris Marker (Manchester and New York: Manchester University Press, 2008)

Corrigan, Timothy, The Essay Film: From Montaigne, After Marker (New York : Oxford University Press, 2011)

Diagne, S. B., Comment philosopher en Islam (Paris: Panama, 2008) 611-12.

- - - - , "Philosopher en Afrique," Critique, LXVII: 771-72 (2011) :

Diabaté, M., "Du sous-développement au blocage au développement," Présence Africaine, 79, no. 3 (1971) : pp. 17-33.

Diop, A., "Niam M'Paya," in R. P. Placide Tempels, La Philosophie bantoue (Paris: Présence Africaine, 2013)

Diop, C.A., The Cultural Unity of Negro Africa. The Domain of Patriarchy and Matriarchy in Classical Antiquity (Paris: Présence Africaine, 1962)

Fabian, J., Remembering the Present: Painting and Popular History in Zaire (Berkeley: University of California Press, 1996)

Fanon, F., Peau noire, masques blancs (Paris: Seuil, 1952)

----- , Les Damnés de la terre, preface by Jean-Paul Sartre (Paris: Maspero, 1961)

Foucault, M., The Order of Things : an Archaeology of the Humans Sciences (London: Tavistock Publications, 2002) 
Fraiture, Pierre-Philippe and Daniel Orrells, eds. The Mudimbe Reader (Charlottesville: University of Virginia Press, 2016)

Goldwater, R., Primitivism in Modern Art, (Cambridge, MA and London: Belknap Press, 1986)

Hountondji, Paulin, "An African philosopher in Germany in the eighteenth century: Anton-Wilhelm Amo," in African Philosophy: Myth and Reality, intro. Abiola Irele and trans. H. Evans and J. Rée (Bloomington: Indiana University Press, 1996), 111-30.

Howe, S., Afrocentrism: Mythical Past and Imagined Homes (London: Verso, 1998)

Jeppie, Shamil and Souleymane Bachir Diagne, The Meanings of Timbuktu (Cape Town: HSRC Press in association with CODESRIA, 2008)

Le Garrec, N. and R. Vautier, "Propos d'Alain Resnais," in MartínezJacquet, E. et al. (eds) Ode au grand art africain: Les Statues meurent aussi (Paris : Primedia, 2011), 35-41.

Marker, C., G. Cloquet and A. Resnais, Les Statues meurent aussi (Paris: Présence Africaine, 1953)

Marker, C., Commentaires 1 (Paris: Seuil, 1967)

- - - - (2010), "Les Statues meurent aussi. Commentaire du film," in Martínez-Jacquet, E. (ed.) Ode au grand art africain: Les Statue meurent aussi (Paris: Primedia, 2010), 27-32.

Martínez-Jacquet, E. et al, eds., Ode au grand art africain: Les Statue meurent aussi (Paris: Primedia, 2010)

Martínez-Jacquet, E., "Un hommage au premier manifeste esthétique sur les arts d'Afrique de l'histoire du cinéma, " in Martínez-Jacquet, E. et al. (eds), Ode au grand art africain: Les Statues meurent aussi (Paris: Primedia, 2010). 18-23.

Mbembe, A., Sortir de la grande nuit: essai sur l'Afrique décolonisée (Paris: La Découverte, 2010)

Mudimbe, VY, "Héritage occidental et conscience nègre," Congo-Afrique, 26 (June-July 1968), pp. 2-14.

- - - - , L'Autre Face du royaume. Une introduction à la critique des langages en folie (Lausanne: L'Age d'homme, 1973)

- - - - , L'Odeur du père: essai sur des limites de la science et de la vie en Afrique noire (Paris: Présence africaine, 1982)

- - - - , The Invention of Africa: Gnosis, Philosophy, and the Order of Knowledge (Bloomington: Indiana University Press; London: James Currey, 1988) 
- - - - - "'Reprendre.' Enunciations and Strategies in Contemporary African Arts," in Susan Vogel (ed.), Africa Explores. 20 th Century African Art (New York: Museum for African Art, 1991), 276-87.

- - - - - , ed., The Surreptitious Speech: Présence Africaine and the Politics of otherness, 1947-1987 (Chicago: University of Chicago Press, 1992)

- - - - , The Idea of Africa (Bloomington: Indiana University Press; London: James Currey, 1994)

Mudimbe, VY and Ngandu Nkashama, P., "Remarques synthétiques sur la contribution africaine à la fondation de la pensée et de la littérature latines chrétiennes," in Mélanges offerts à Léopold Sédar Senghor: langues littérature - histoire ancienne (Dakar: Nouvelles Editions Africaines, 1977), 356-74.

Mveng, E., L'Art et l'artisanat africain (Yaoundé: Clé, 1980)

Obenga, T., L'Afrique dans l'Antiquité. Egypte pharaonique, Afrique noire (Paris: Présence Africaine, 1973)

- - - - La Philosophie africaine de la période pharaonique, 2780-330 avant notre ère (Paris: L'Harmattan, 1990)

Payot, D., L'Art africain entre silence et promesse (Strasbourg: Les Editions Circé, 2009)

Radin, Paul, Primitive Man as Philosopher (New York \& London: D. Appleton and Company, 1927)

Sartre, J.-P., Being and Nothingness: an Essay on Phenomenological Ontology (London and New York: Routledge, 1989)

- - - - , "Orphée noir," Léopold Sédar Senghor (ed.), Anthologie de la nouvelle poésie nègre et malgache de langue française, avant-propos de Ch.André Julien (Paris: PUF, 1948), ix-xliv.

- - - - "Preface," in F. Fanon, Les Damnés de la terre, pp. 9-26.

Sumner, C., Ethiopian Philosophy, vol. II: The Treatise of Zera Yacob and Walda Heywat. Text and Authorship (Addis Ababa: Commercial Printing Press, 1976)

Tempels, P., Bantu Philosophy (Paris: Présence Africaine, 1959)

Tylor E.B., Primitive Culture, with an introduction by Paul Radin (New York: Harper, 1958)

Vansina, J., Art History in Africa (London and New York: Longman, 1984) 
1 See, among many other examples, the recent special issue of Actuel Marx dedicated to Fanon, "Philosophe et penseur politique majeur" - “Major philosopher and political thinker” (2014: 7).

2 See https://www.youtube.com/watch?v=JOH3-CkM_kg [accessed on 22 July 2015]

${ }_{3}^{3}$ See http: / / www.theguardian.com/artanddesign/2014/dec/01/turner-prize-2014-duncan-campbellwins [Accessed on 22 July 2015].

${ }^{4}$ See http://lux.org.uk/collection/works/bernadette [Accessed on 23 July 2015]

5 Alongside prominent private collectors such as Hans Hartung and Tristan Tzara, their representatives are all duly thanked in the opening credits of the documentary

${ }^{6}$ A. Diop's preface ("Niam M’Paya”) is not numbered.

${ }^{7}$ The documentary was made between 1950 and 1953 (Cooper: 12).

${ }^{8}$ Interestingly, the editors of the catalogue of the 2010 exhibition dedicated to Les Statues meurent aussi (Martínez-Jacquet, E. et al.) chose a Luluwa (DRC) "figure de maternité" for their front cover.

${ }^{9}$ On this shift in art history in Africa, see Vansina's “The Artist as Creator” (1984: 136-140).

10 "Reprendre" is reproduced in "Visual Culture," the fourth and last part of The Mudimbe Reader, Pierre-Philippe Fraiture and Daniel Orrells, eds. (Charlottesville: University of Virginia Press, 2016). Two essays discussed below - the French “L'Un et ses autres," translated into English ("The Self and Its Others”), and "From 'Primitive Art' to 'Memoriae Loci' “ are both reproduced in "Visual Culture" in The Mudimbe Reader.

11 See his critique of the re-appropriation of Bernal's theses in the US (Mudimbe 1994: 103-04).

12 It For Others (Middle Part): https://www.youtube.com/watch?v=7z6SCDeh4_A [last accessed 24 July 2015].

${ }^{13}$ See https: / / www.youtube.com/watch?v=JOH3-CkM_kg

14 She is most probably referring to the following articles by Moustapha Diabaté: "Du sousdéveloppement au blocage au développement," Présence Africaine, 79 (3), 1971, pp. 17-33. Diabaté deplores the return to "feudal" practices on the part of contemporary African regimes (31) and their regular misappropriation of public funds at the expense of development projects (32). 